UDK 322(439:456.31)"1472"

929 Matijaš Korvin, hrv.-ug. kralj

929 Nyujtodi Szekely, Miklos

Primljeno: 9. 2. 2017.

Prihvaćeno: 1. 6. 2017.

Izvorni znanstveni rad

DOI: $10.22586 /$ pp.v52i0.5

\title{
King Matthias Corvinus and the Papacy in Early 1472: Miklós Nyújtódi Székely in Rome ${ }^{*}$
}

\author{
Antonín Kalous \\ Katedra historie Filozofické Fakulty \\ Univerzity Palackého v Olomouci \\ Křížkovského 10 \\ 77180 Olomouc \\ Czech Republic \\ E-mail: antonin.kalous@upol.cz
}

Relations of King Matthias Corvinus and the papacy have been studied by many historians since the nineteenth century. Uncovering and publishing sources that would elucidate this part of papal and central-European history was of prime interest. This paper tries to bring some new light to these relations thanks to a newly discovered instructions of the king to his envoy, Miklós Nyújtódi Székely, bishop of Knin, who travelled to Rome sometime in the beginning of 1472. On the basis of these instructions we can reconstruct the king's intentions and plans in the context of the political situation of central Europe in the early 1470s. At that time, relations to Bohemia and Poland set the framework of the policies, which were influenced from the papal side by the present papal nuncios, especially Lorenzo Roverella.

Key words: papacy, papal diplomacy, Lorenzo Roverella, Matthias Corvinus, Hungary, Bohemia, central Europe, Miklós Nyújtódi Székely, diplomacy

In his classical study, Vilmos Fraknói wrote about a number of Hungarian diplomats in the service of Matthias Corvinus. ${ }^{1}$ In general, the king's diplomatic body

\footnotetext{
This study was prepared within the project of Grant Agency of the Czech Republic nr. 13-01279S.

1 Vilmos Fraknói, "Mátyás király magyar diplomatái” [Hungarian diplomats of King Matthias], Századok 32 (1898): 1-14, 97-112, 385-404, 481-489, 769-781, 865-875; 33 (1899): 1-8, 291-309, 389-410, 773-787, 869-878.
} 
was much larger, as it comprised not only Hungarians, but also inhabitants of his other countries and lands as well as Italians, who were involved in the diplomatic service in Italy and elsewhere. Thus, Fraknói's study, even though it is still used and will continue to be used as the basic source of information on a number of diplomats, can always be improved and complemented. This little paper, however, does not intend to provide another new or hitherto unknown diplomat. Quite on the contrary, the subject of this study is the activity of Miklós (Nicholas) Nyújtódi Székely, bishop of Knin and holder of other important ecclesiastical benefices. ${ }^{2}$

King Matthias Corvinus tried to increase royal power in late medieval Hungary, to which purpose he used strategies that enabled him to improve his standing in internal politics and on the international level. For both, he used homines novi, new men, who gave him their talents and efforts. In order to secure their support, Matthias had at his disposal, like his predecessor King Sigismund, high benefices of the Hungarian church. Canons and bishops were newly nominated by King Matthias and often served in his court or land offices, as well as in royal diplomacy. ${ }^{3}$ Miklós Nyújtódi was one of such men. He came from the Transylvanian nobility and, like many other and later diplomats, pursued university studies. First he studied in Vienna (1448-1456) and later on in Padua (1465), which made him an ideal person for diplomatic service. Italian experience was always highly valued by kings and princes beyond the Alps. At least in the Central European context, well-educated bishops and high prelates often played a decisive role in diplomatic service. Unlike in Italy, where career diplomats and ambassadors mainly belonged to the rank of chancellors and secretaries of the prince, while prelates and aristocrats fell into the category of occasional diplomats, ${ }^{4}$ in Hungary

\footnotetext{
2 Ibid., Századok 33 (1899): 5-7; József Köblös, A budai, fehérvári, győri és pozsonyi káptalan archontológiája, 1458-1526 [An archontology of the chapters of Buda, Fehérvár, Györ, and Pozsony] (Budapest: Magyar országos levéltár, 1987), 85, no. 79; József Köblös, Az egyházi középréteg Mátyás és a Jagellók korában (A budai, fehérvári, györi és pozsonyi káptalan adattárával) [The ecclesiastical central layer in the period of King Matthias and the Jagiellonians (With the database of the chapters of Buda, Fehérvár, Győr and Pozsony /Bratislava/)] (Budapest: MTA Történettudományi Intézete, 1994), 359-360, no. 79; Norbert C. Tóth, Richárd Horváth, Tibor Neumann, and Tamás Pálosfalvi, Magyarország világi archontológiája 1458-1526. I. Föpapok és bárók [An archontology of Hungary, 1458-1526; I. Prelates and barons] (Budapest: MTA Bölcsészettudományi Kutatóközpont Történettudományi Intézet, 2016), 41. In historiography Miklós is known as Miklós Nyújtódi or Miklós Nyújtódi Székely, i.e. Miklós Székely of Nyújtód (present-day Lunga) in Transylvania, today in Romania, near Braşov. I have used the shorter version and do not switch between the two for clarity.

3 For a general overview of the development of government and offices, see Pál Engel, The Realm of St Stephen: A History of Medieval Hungary, 895-1526 (London: I. B. Tauris, 2001), 209-344; András Kubinyi, Matthias Corvinus: Die Regierung eines Königreichs in Ostmitteleuropa 1458-1490 (Herne: Tibor Schäfer, 1999); András Kubinyi, Matthias Rex, trans. Andrew T. Gane (Budapest: Balassi Kiadó, 2008). In detail on the prelates: Elemér Mályusz, Egyházi társadalom a középkori Magyarországon [Church society in medieval Hungary] (Budapest: Akadémiai Kiadó, 1971); György Bónis, A jogtudó értelmiség a Mohács előtti Magyarországon [The legal intelligentsia in Hungary before Mohács] (Budapest: Akadémiai Kiadó, 1971).

4 Isabella Lazzarini, Communication and Conflict: Italian Diplomacy in the Early Renaissace, 1350-1520 (Oxford: Oxford University Press, 2015), 123-145.
} 
the involvement of clergy was rather a rule. Thus, Miklós Nyújtódi, as a canon in Székesfehérvár (1453 - 1474) and later a cantor (1477 - 1484) and canon in Veszprém (1470 - 1484) as well as - most importantly - the bishop of Knin (1467 - 1489), followed the career of other - maybe more famous - diplomats such as John Vitéz, Janus Pannonius, György Handó, Prothasius of Boskovice, Jan Filipec, John Vitéz the Younger, and many others. Nyújtódi died sometime between 1489 and $1492 .^{5}$

Nyújtódi was one of the many ambassadors of the Hungarian king to the Roman papal court, communication with which was very frequent. ${ }^{6}$ In the second half of the fifteenth century, Rome was becoming a centre of international diplomacy, creating a multicultural and multinational setting for diplomatic activities. Recently, the study of diplomacy in Rome has been enriched with two crucial publications. First, it is the invaluable edition of an early sixteenth century treatise on ambassadors in Rome by Paride Grassi, which was for a long time studied only in manuscript. ${ }^{7}$ The second book is a study on the resident ambassadors in Renaissance Rome by English historian Catherine Fletcher. ${ }^{8}$ These volumes cannot help in finding new information on the activities of Miklós Nyújtódi, but they provide an important background for any such study. Miklós Nyújtódi was not a resident ambassador: he visited Rome several times, but only for brief periods of time, unlike some others, most significantly John Vitéz the Younger in the 1480s. According to the available sources, Miklós Nyújtódi was present in Rome three times; first in 1467, when he was confirmed as the bishop of Knin. ${ }^{9}$ Not much is known, however, of his other activities in Rome. The second time he went to Rome was during the first year of the pontificate of Sixtus IV; and again his activities have not been known to scholarship. ${ }^{10}$ Finally, he visited the City in 1480 together with John Vitéz the Younger. Their tasks can be deduced from

\footnotetext{
5 Köblös, Az egyházi középréteg, 359; C. Tóth, Horváth, Neumann, Pálosfalvi, Magyarország világi archontológiája, 41.

6 An overall list can be found in Jolán Balogh, A müvészet Mátyás király udvarában [Art at the court of King Matthias] (Budapest: Akadémiai Kiadó, 1966), vol. 1, 674-675.

7 Biblioteca Apostolica Vaticana (hereafter BAV), Vat. lat. 12270; and the recently published edition of the treatise, Philipp Stenzig, Botschafterzeremoniell am Papsthof der Renaissance: Der Tractatus de oratoribus des Paris de Grassi - Edition und Kommentar, 2 vols. (Frankfurt am Main: Peter Lang, 2013).

8 Catherine Fletcher, Diplomacy in Renaissance Rome: The Rise of the Resident Ambassador (Cambridge: Cambridge University Press, 2015). She focuses mostly on Western Europe, even if the system of ambassadorial representation was universal to all parts of Europe and all secular rulers who sent their ambassadors to the Holy See.

9 Fraknói, "Mátyás király magyar diplomatái", 33 (1899): 5; Fraknói, ed., Mátyás király levelei, külügyi osztály (Letters of King Matthias, foreign section), 2 vols. (Budapest: Magyar tudományos akadémia, 1893-1895), vol. 1, 196, 199.

${ }^{10}$ Fraknói, "Mátyás király magyar diplomatái", 33 (1899): 5; Augustin Theiner, ed., Vetera monumenta historica Hungariam sacram illustrantia. Vol. 2, Ab Innocentio PP. VI. usque ad Clementem PP. VII, 13521526 (Roma: Typis Vaticanis, 1860), 435, no. DCXVII.
} 
the then correspondence between the Holy Father and the King of Hungary, as Fraknói showed in his study. ${ }^{11}$

For the fifteenth century, it is often difficult to find out details about the actual activities, tasks, and assignments of individual ambassadors to Rome. Thus, it is always with a great deal of luck that new sources are discovered, which may illustrate the stays and activities of ambassadors in Rome. In case of Miklós Nyújtódi, there are a few sources that have hitherto not been used and that elucidate his second stay in Rome early in 1472. Biblioteca Angelica in Rome, at St Augustine's church, holds a manuscript containing a large number of texts, letters, charters, reports, and relations copied by a single scribe in 1510, as the first page of the manuscript announces. ${ }^{12}$ The manuscript contains documents from the second half of the fifteenth and the early sixteenth century, all of which were carefully catalogued in $1893 .{ }^{13}$ The catalogue, however, could not get behind the text and identify all the persons appearing in individual letters - 218 numbers are listed for the manuscript - and thus it happened that the text given in the catalogue as "Informatio D. Tinimen. (!) ex parte Maiestatis Regie" remained unnoticed by the historians. ${ }^{14}$ This text, however, is crucial for the tasks of Miklós Nyújtódi in Rome in 1472 and for understanding the needs and the policy of Matthias Corvinus during the same period in relation to the papal diplomacy in Central Europe. Before I analyse the text itself, it would be helpful to have a look at another document that is preserved, in this case, in the Biblioteca Apostolica Vaticana. It is a report by Marco Barbo, cardinal and legate to Germany and Central Europe in $1472-1474 .{ }^{15}$ Cardinal Marco Barbo was a close relative of the Venetian Pope Paul II, Pietro Barbo, and was appointed legate by his successor, Pope Sixtus IV, on 22 December 1471 together with four other cardinals. He left Rome two months later, on 22 February 1472, and - as will be argued later on - Miklós Nyújtódi may have met the cardinal in Rome already during this period and even joined his retinue during a journey to Central Europe. Marco Barbo is known to have reported to the consistory after his return about the results and events of

\footnotetext{
${ }^{11}$ Fraknói, "Mátyás király magyar diplomatái", 33 (1899): 5-6; Fraknói, ed., Mátyás király levelei, vol. 2, 19, 46-70.

${ }_{12}$ Roma, Biblioteca Angelica, ms. 1077, fol. 1r, Virginei partus anno $+M D X+$ die prima bicipitis dei hunc incepi adscribendum librum, sol in m existente, in * aspectu, luna iarietis atque $ठ$ in castro montis martis hora XX.a diei, in talamo meo solito, ubi varie rescriptis erunt. Nomen libri erit multarum herbarum, cum nomine Ihesu, atque semper virginis Marię inceptum, ipsis cum eorum nomine, ut compleatur placeat, et nobis gratiam faciant, ut completi sub eorum nomine possim atque auxilio, suorumque etiam omnium sanctorum. AMEN.

${ }^{13}$ Henricus Narducci, Catalogus codicum manuscriptorum praeter graecos et orientales in Bibliotheca angelica olim coenobii sancti Augustini de Urbe, Tomus prior (Roma: Ludovico Cecchini, 1893), 438-449. ${ }^{14}$ Ibid., 440.

${ }^{15}$ Antonín Kalous, Plenitudo potestatis in partibus? Papežští legáti a nunciové ve střední Evropě na konci středověku (1450-1526) [Papal legates and nuncios in late medieval Central Europe (1450-1526)] (Brno: Matice moravská, 2010), 245-284.
} 
his mission. ${ }^{16}$ The text, which clearly is a concept for a part of this report, or a report sent to Rome earlier on, ${ }^{17}$ contains further information on Miklós Nyújtódi. However, we do not learn anything about his activities in Rome, but rather about his later communication with the legate in Central Europe. Upon his return from Rome, ${ }^{18}$ Nyújtódi rejoined the court of Matthias Corvinus and was in frequent contact with Cardinal Marco Barbo, who actively worked on the cooperation of Central European kings and whose main task was to secure peace among them. The bishop of Knin met several times with Leonardo Mansueti da Perugia, a Dominican friar and magister sacri palacii who accompanied Marco Barbo on his legation and functioned as his messenger. For example, Leonardo was sent from Krakow to Buda with a draft of a truce agreement between the kings of Poland and Hungary on July $11,1472 .{ }^{19}$ On his way back to the legate's court, where he arrived towards the end of August, he was accompanied by Miklós Nyújtódi, who explained why King Matthias could not accept the truce: he did not agree with the conditions of releasing Victorin, son of the late King George of Podébrady, whom he kept in captivity. The bishop of Knin brought his version of the truce agreement, but this one, in return, was rejected by King Casimir and his barons. ${ }^{20}$ On September 9, 1472 the two envoys - Mansueti and Nyújtódi - were sent by the legate to Nowy Sącz close to the Polish-Hungarian border, where they were to await his response after the talks he planned to have personally with the Polish king. A week later, Barbo instructed Mansueti about everything he negotiated with King Casimir; however, he did not meet Nyújtódi as the latter did not wait and left for Hungary before the legate's arrival. Nevertheless, the cardinal ordered another prelate in his retinue, Leonello Chieregato, bishop of Rab in Dalmatia (perhaps because he was also a Dalmatian bishop like Miklós), to write detailed instructions to Miklós Nyújtódi; the legate added an explanation of the new conditions of the truce (especially concerning Victorin) in his own hand. Mansueti then carried the letter to the Hungarian court, where he was to act together with the bishop of Knin. ${ }^{21}$

\footnotetext{
${ }^{16}$ Iacopo Ammannati Piccolomini, Lettere (1444-1479), ed. Paolo Cherubini (Rome: Ministero per i beni culturali e ambientali, Ufficio centrale per i beni archivistici, 1997), vol. 3, 1890 - 1891, no. 767.

${ }^{17}$ BAV, Vat. lat. 5641, fol. 201r-208v; ed. in Kalous, Plenitudo, 264-284.

${ }_{18}$ Theiner, ed., Vetera monumenta, vol. 2, 435, no. DCXVII; he left Rome before March 12, 1472.

19 BAV, Vat. lat. 5641, fol. 205r; ed. in Kalous, Plenitudo, 274.

${ }^{20}$ BAV, Vat. lat. 5641, fol. 206r-207r; ed. in Kalous, Plenitudo, 277-278.

${ }^{21}$ BAV, Vat. lat. 5641, fol. 207v; ed. in Kalous, Plenitudo, 280-281; Hec eadem iussi episcopo Arbensi scribere domino electo Tiniensi et ego in ipsis litteris plura manu propria scripsi, inter que pro dono precipuo petivi prorogationem relaxationis Victorini modo predicto et hoc feci, ut dominus Tiniensis omnia referret domino regi Ungarie et una cum magistro sacri palatii rem hanc apud maiestatem suam tractaret. Cum hiis instructionibus et litteris dominus magister sacri palatii ad dominum regem Ungarie profectus est. Jan Długosz knew about this cooperation as well, but together with Mansueti he gives the name of Ioannes Thininensis (or Tininensis) episcopus, identified by the editors as Iohannes Valens, ep. Tinenensis (from the diocese of Bath and Wells in England!) according to Conrad Eubel, Hierarchia catholica medii
} 
Clearly, Miklós Nyújtódi was considered an important envoy and negotiator at the court of Matthias. He may have gained the trust of Cardinal Marco Barbo during their previous meetings and possibly talks in Rome, or on the way if they travelled together. As mentioned earlier, Miklós was sent to Rome by the king early in 1472. The reason is not clearly known, but - coming back to the "Informatio" - the instructions of King Matthias shed light on Miklós' tasks in Rome, possibly on his dealings with the new legate to Central Europe, and subsequently on Matthias' policy during the early 1470 s. $^{22}$

The text of the "Informatio domini Tininien. ex parte maiestatis regie," as it is titled in the manuscript, contains instructions and argumentations that are divided into ten articles/paragraphs. They all have much in common, namely a discussion of the current Central European situation in relation to papal diplomacy in the region. In the beginning, the bishop of Knin is advised to say that the king was very much surprised and disturbed when he learned that the pope intended to send another legate. This is the basic statement and all the ten articles bring arguments in favour of keeping the situation as it was.

The king understands the papal decision only as something based on the suggestions of his enemies and reminds the pope that he has brought himself into more danger for the apostolic see than any other king (article 1). If the present legate were recalled and a new one sent, he might do a lot of damage to the cause of faith and the matters of the king before he can understand the "lies of the Poles and the tricks of the heretics" (2). Under the present legate the king understood Lorenzo Roverella, bishop of Ferrara and a nuncio cum potestate legati de latere, who had been present in the region from the late 1450s. As a learned theologian he joined Cardinal Juan Carvajal on his second legation to Germany and Hungary in 1457. In the early 1460s, he was active as a nuncio in France and Burgundy, and upon his return to Rome in 1462 he closely cooperated with Pius II. His next mission to Central Europe took place only in 1467, when he was commissioned by Pope Paul II to act as a papal nuncio at the Nuremberg diet. In January 1468, his office was extended to include other lands of Central Europe, especially Hungary, and he gained the title of nuncio cum potestate legati de latere. His tasks included fighting the Hussite heresy and King George of Bohemia and cooperating with the kings of Poland and Hungary; furthermore, he was entitled to preach the crusade, publish indulgences, and collect money. Generally, it was the anti-Czech and anti-Hussite fight that was his crucial assignment. Without going into detail, it is clear that

aevi sive Summorum pontificum, S. R. E. cardinalium, ecclesiarum antistitum series ab anno 1431 usque ad annum 1503 perducta (Munich: Libraria Regensbergiana, 1914), 251. I believe that it was not the said person, but a mistake by Długosz in the first name, cf. Joannes Dlugossius, Annales seu Cronicae incliti regni Poloniae, Liber duodecim, 1462-1480, ed. Krzysztof Baczkowski et al. (Krakow: Polska Akademia umiejętności, 2005), 292.

${ }^{22}$ Rome, Biblioteca Angelica, ms. 1077, fol. 36v-38v. See Appendix. 
Lorenzo took over the initiative from the aging Rudolf of Rüdesheim. Together with Rudolf and another papal nuncio, Gabriele Rangoni, they represented papal policy in the region even in the sphere of highest political negotiations. They were present when Matthias was elected King of Bohemia in Olomouc (1469) and also when Matthias wanted to be re-elected by the Bohemian land diet in 1471, after the death of King George. When rejected, Matthias forced Lorenzo to confirm him as the king of Bohemia in Jihlava. In a well-known report to the pope, the bishop of Ferrara complained that he was compelled to do that right after the king learned about the outcome of the election diet in Kutná Hora, which elected King Wladislas II Jagiellonian, son of Casimir IV, King of Poland. ${ }^{23}$

Even though the relations between the king and the then "legate" were not always ideal, it is clear that the king had gotten used to him and that he considered Lorenzo Roverella a useful partner in his dealings with the current political situation. The king then continues in his "Informatio" on the same note, claiming that the Poles would say that the pope's decision only confirmed that they were right and that the current legate did everything only de suo capite (3). The Poles would, moreover, celebrate that the pope is on their side and that he understood the justice in this case (4). This, the king said, would be very dangerous for the situation of the Catholics in Bohemia, who would be weakened and their position jeopardized by the stronger Utraquists supported by the lies of the Poles and by access to the son of the king of Poland, who is "now in Prague" (5). Revoking the current legate would cause scandals everywhere - "not only among the Bohemians, but in all other regions" - because he was the legate who confirmed Matthias as the king of Bohemia with apostolic authority. It was always promised that the apostolic see would never give up this claim, but now it would be believed that the pope deceived the king (6). The king of Hungary feels it important to remind the pope of the confirmation, which was expected long ago and was still not coming. The confirmation of nuncio Lorenzo Roverella was mentioned above.

This last argument concerning Lorenzo was quite strong. Cardinal Marco Barbo was granted the authority (facultas) to confirm the election of King Matthias as the king of Bohemia and thus the former confirmation of nuncio Lorenzo Roverella. ${ }^{24}$ The conditions on which this authority could be used, however, were specified in the instructions for the legate published just five days later: it could be used only in case when there was no longer any hope of reaching peace through negotiation. ${ }^{25}$

\footnotetext{
${ }^{23}$ Archivio Segreto Vaticano (hereafter ASV), Arm. XXXIX 12, fol. 173r-174v; ed. in Theiner, ed., Vetera monumenta, vol. 2, 422-423, no. DCIII; cf. Kalous, Plenitudo, 217-227.

${ }^{24}$ ASV, Reg. Vat. 680, fol. 84r-85r (14 May 1472); ed. in Kalous, Plenitudo, 254-256.

${ }_{25}$ ASV, Misc., Arm. II 30, fol. 41r-42r; ed. in Kalous, Plenitudo, 256-258; Quo ad tertium capitulum de confirmatione electionis factae regis Hungariae, expediatur bulla in bona forma, et mittatur ad legatum; illa tamen utatur pendente tractatu concordiae, nisi viderit eandem confirmationem utilem et necessariam ad pacem melius et celerius consequendam, eodem vero tractatu iam omisso et pacis nulla remanente spe,
} 
Even though Kings Matthias and Casimir did not reach any agreement before Marco Barbo left, there is no trace of using this faculty and confirming Matthias as the king of Bohemia. However, a contemporary copy of papal confirmation is kept in the archives of Třeboň: the pope confirmed the king almost four years later, on December 9, 1475, in a letter addressed to the adherents of King Matthias in Bohemia, Moravia, Silesia, and the Lusatias. ${ }^{26}$ To complete the picture it may be added that King Wladislas, the firstborn son of Casimir, king of Poland, was confirmed by the pope as the king of Bohemia only on May 18, 1487: it was by Pope Innocent VIII, on the occasion of an obedience embassy sent by the king. ${ }^{27}$

The seventh article then concludes, concerning the keeping of Lorenzo Roverella in his position, that calling off the nuncio would mean deriding the king and that everyone would understand it as a destructive act. Instead, the papal nuncio should be confirmed; not only because of the person himself, even though the king does love the bishop of Ferrara for his virtues, enthusiasm for the Catholic faith, and justice, but also because of the current state of affairs.

To prove the point with even stronger arguments, King Matthias wanted Miklós to stress the devastation that the Polish invasion had brought to Hungary, and that it was connected to the plot against the king. According to the instructions, the bishop of Knin was ordered to say that the Poles, together with the heretics and the Tartars, carried out such despicable and vicious crimes that even pagans could not do. They plundered and damaged churches, stole and desecrated the holy relics, which they threw away in order to steal the golden and silver reliquaries. Moreover, they trampled upon the Eucharist, ravished and violated virgins, robbed and killed the poor. This is a stereotypical set of accusations referring to an invasion by an external foe. However, such rhetoric must also have been used to support Matthias's argumentation. Nyújtódi was instructed to add that all the Poles had been expelled, killed, or taken into captivity and their equipment and wagons captured. This was intended to show the pope that the king had many enemies; therefore, the pope was to understand that it was a dangerous situation for the king, who was surely willing to make an agreement in worldly matters, but such enemies should always be rewarded adequately (8). This incursion of Prince Casimir, the second son of the Polish king, and the conspiracy led by John Vitéz and Janus Pannonius are well known in Hungarian scholarship. Clearly, the motives behind them would have been different for different parties - in case of

tunc poterit uti illa facultate, et dictam electionem confirmare, prout melius expedire suae prudentiae videbitur (fol. 42r; p. 258).

${ }^{26}$ Státní oblastní archiv (State regional archives) Třeboň, Historica, inv. no. 3516, sign. 2883. The document is preserved as a contemporary unconfirmed copy.

${ }^{27}$ Josef Macek, "Prag und Rom am Ende des 15. Jahrhunderts: Zum Verhältnis der päpstlichen Kurie zur böhmischen Reformation", in: Historische Blickpunkte: Festschrift für Johann Rainer, ed. Sabine Weiss (Innsbruck: AMOE, 1988), 391-403, here 402. 
John Vitéz and Janus Pannonius, the historians even mention an attempt to stop the war against Bohemia. ${ }^{28}$ The problematic nature of the Bohemian war, which brought destruction even to Hungary, has been mentioned also on the Polish side, namely in the work of Jan Długosz, who also confirmed that there were one thousand Tartars in the invading army. ${ }^{29}$

Further instructions for the bishop of Knin concern the current papal policy. The king even slightly criticizes the pope for writing so many letters to the heretical Bohemians, and then again tries to strengthen his own position in the eyes of the papacy, claiming that he has put himself into danger and suffered destruction in his own kingdom only for his reverence to the apostolic see. He has never wanted to fight against Christians, unless he was forced to do so. When the son of the Polish king went to Bohemia, the Polish king did not assent to negotiations, which the king of Hungary was prepared to lead. On the contrary, Casimir trusted the traitors, who reported of Matthias' death and promised to give him also the kingdom of Hungary. At this point, it was clear to the king of Hungary that he had to strike against the traitors, who - by now - had all been expelled from the country (9). Here Matthias indirectly stressed his main task and the main task of the papacy, which was to fight against the Turks. Even though he did not actively fight at that point, it was fighting the Christians, which he was forced to do, that distracted him from the main goal. For the papacy, again, this was the proper rhetoric to prove his point.

Concerning the papal attempts to secure peace in the region, the king mentions the activity of the papal nuncio Tilmann Schlecht, who came to Poland and Hungary in autumn 1471, just at the time of the Polish invasion. The nuncio should report himself to the pope on what he talked about in Poland, but the king could account for all his deeds, when interrogated (9). Tilmann Schlecht was a canon in Cologne, but - like many others - had experience from the region from the second legation of Cardinal Juan Carvajal to Germany and Hungary; he served as a notary in the retinue of the legate. ${ }^{30} \mathrm{He}$ reached Krakow early in November and

\footnotetext{
${ }^{28}$ Dlugossius, Annales, 275-287; Antonius de Bonfinis, Rerum Ungaricarum decades, ed. I. Fógel, B. Iványi, and L. Juhász (Budapest: Egyetemi Nyomda, 1941), vol. 4, 40-48; Krzysztof Baczkowski, Walka Jagiellonów z Maciejem Korwinem o koronę czeska w latach 1471-1479 (Jagiellonian war against Matthias Corvinus for the crown of Bohemia in 1471-1479) (Krakow: Uniwersytet Jagielloński, 1980), 4858; András Kubinyi, "Vitéz János és Janus Pannonius politikája Mátyás uralkodása idején” [Policy of John Vitéz and Janus Pannonius during the rule of King Matthias], in: Humanista müveltség Pannóniában [Humanist culture in Pannonia], ed. István Bartók, László Jankovits and Gábor Kecskeméti (Pécs: Művészetek Háza-Pécs Tudományegyetem, 2000), 7-26; András Kubinyi, "Vitéz János: a jó humanista és rossz politikus" [John Vitéz: a good humanist and a bad politician], in: A magyar történelem vitatott személyiségei [The controversial figures of Hungarian history], vol. 2 (Budapest: Kossuth Kiadó, 2003), 7-30; Antonín Kalous, Matyáš Korvín (1443-1490): Uherský a český král [Matthias Corvinus (14431490): King of Hungary and Bohemia] (České Budějovice: Veduta, 2009), 158-161.

${ }^{29}$ Dlugossius, Annales, 275-276.

${ }^{30}$ Magyar Nemzeti Levéltár, Országos Levéltár, DL 14462 (May 29, 1456).
} 
planned to continue his peace talks in Hungary in December. All was, however, ruined by the new military activities and aspirations of Prince Casimir. ${ }^{31}$

The king summarized his conclusion in the tenth paragraph, asking the pope to act swiftly and confirm all the queries of the bishop of Knin if he wanted to achieve anything against the Turks and the heretics. Most importantly, he should not believe the Poles, "who are not afraid of God and do not respect any people" and who support the heretics. They are not afraid of losing their soul for robbery and have even occupied - again quite an important rhetorical element - the property and patrimony of St Peter and the Order of the Virgin Mary (i.e. the Teutonic knights), deriding excommunication. The king wishes that the pope would trust him at least in his deeds and confirm what was suggested in the instructions to the bishop of Knin. What is crucial, the king will not act without the consent of the legate and his nuncios. If the situation is going to develop against the king's will, however, he will be free of guilt: although he has always put his person and his kingdom in danger, if deserted by all who have been helping him so far, he will not be able to withstand the enemies (10).

The text of the instructions for the bishop of Knin Miklós Nyújtódi, which has been partially retold here, not only fits perfectly the current political situation at the turn of 1471/1472, but also contributes to the understanding of the turbulent times after the death of the Bohemian king George of Poděbrady and the Polish involvement in Bohemia and Hungary. Miklós Nyújtódi was the carrier of information and the presenter of the king's argumentation, which was intended to win the pope's support for Matthias' policy. It can be seen that the king was not quite sure of this support although modern scholarship does not doubt it. The reason was, of course, the Bohemian affairs. The king was not confirmed as the king of Bohemia by the pope until 1475; the legatine confirmation was administered by the nuncio cum potestate legati de latere Lorenzo Roverella in 1471, but it had to be forced; when the relation with Roverella worked well (or at least it was presented as such by the king), Matthias was afraid that the nuncio would be exchanged for a new legate, who would not understand the region and the problems. This may have been the original reason for sending Miklós Nyújtódi to Rome early in 1472: namely, to explain the king's position and to secure the continuation of papal policy in the person of Roverella. The king could not stop the appointment of a new legate, but Nyújtódi's action was definitely not a failure. It is clear that Cardinal Marco Barbo was well informed about the situation and about the king's problems. The details of all the instructions of Marco Barbo cannot be included in this paper, but they show that he was prepared to divide the kingdom of Bohemia or confirm Matthias as its king. The talks between the Kings of Poland and

31 Dlugossius, Annales, 278-279; Berthold Kronthal and Heinrich Wendt, eds., Politische Correspondenz Breslaus im Zeitalter des Königs Matthias Corvinus, erste Abtheilung, 1469-1479 (Breslau: Josef Max \& Comp., 1893), 78-79, no. 109; cf. Kalous, Plenitudo, 244-245. 
Hungary belonged to the main points of his legation, which was planned to bring peace to the region in order to create the conditions for the more important fight or even crusade against the Turks. Miklós Nyújtódi, then, was a part of the negotiations as an envoy between the legate, whom he tried to stop in Rome, and the king, who (despite his originally low expectations) could not have much cause for complaint about Cardinal Marco Barbo. 


\section{APPENDIX}

Instructions for Miklós Nyújtódi, an envoy of Matthias Corvinus, king of Hungary and Bohemia, to Rome early in 1472, where he was to negotiate with Pope Sixtus IV or the papal curia in general. The instructions must have been written in early 1472 as a reaction to the news from Rome about the new legates appointed by Sixtus IV on December 22, 1471; among others, Cardinal Marco Barbo for Germany, Hungary, Poland, and Bohemia. When the news reached the royal court of Hungary, the envoy was sent to Rome to stop the legate, who was to leave Rome on February 22, 1472. Thus, there were two months in which Nyújtódi could have negotiated in Rome.

Rome, Biblioteca Angelica, ms. 1077, fol. 36v-38v

Informatio domini Tininien. ex parte maiestatis regie.

In primis, dicat Tinen. sanctissimi domini nostri pape, quod maiestas regia percepto, quod sanctitas sua alium legatum mittere vellet, plurimum turbata fuit. Primo quia non potest intelligere, quod hoc fiat, nisi ad suggestionem inimicorum suorum et ideo gravissime fert, quod ipse, qui exposuit se et sua a tanta pericula, ad quanta nullus rex legitur pro sancta sede apostolica, debeat postponi illis, qui non solum irriserunt et irrident ipsam sedem apostolicam et fidem catholicam, sed etiam ipsam sedem apostolicam et mandata eius sepius fecerunt et faciunt. Unde quid debeat ex hoc vel sperare vel tamen potest ipse papa et alii cogitare.

$2^{\circ}$. Quia si iste legatus ${ }^{32}$ revocatur et alius ${ }^{33}$ mittitur, antequam ille novus intelligat istas res et negocia, presertim mendacia Polonorum et fraudes hereticorum, multa mala faceret tam rebus fidei, quam rebus ipsius regis.

$3^{\circ}$. Quia Poloni et heretici gloriabuntur de hoc et dicent, quod papa fovet partes eorum, ideo revocavit illum legatum, qui de suo capite omnia fecit contra ip[s]os et quod nunquam papa talia conmisit, nam si ausi sunt, talia dicere legato ipso in legatione existente multo magis dicent ipso habeunte.

$4^{\circ}$. Gloriabuntur ipsi Poloni, quod ipsi huius rei fuerunt auctores et quod ad nutum et voluntatem eorum papa hoc fecerit, unde et proclamabunt, quod papa cum eis teneat, sicuti clamant et gloriantur de imperatore et multis aliis et ubique diffamabunt, quod papa cognita iustitia eorum hoc fecerit et velit, quod ipsi in rebus eorum habeant progressum.

\footnotetext{
${ }^{32}$ Lorenzo Roverella, papal nuncio.

${ }^{33}$ Marco Barbo, papal legate de latere (the identity of the legate was not yet known to the king).
} 
$5^{\circ}$. Qui ex hac sequentur inmediate isti duo effectus. Primus, quod heretici, qui nunc iterum incipiunt animis debilitari et cum ipso filio Poloni, ${ }^{34}$ qui est in Praga, satis male convenire et gratiam domini regis querere de uno firmabuntur tam in erroribus eorum, quam in adhesione dicti Poloni. Secundus effectus erit, quod omnes catholici in Boemia, non ${ }^{35}$ solum, qui neutrales perseverant, sed etiam, qui sunt maiestati regie subditi, debilitabuntur animis, et mendaciis Polonorum et ipsorum hereticorum, qui nunquam cessant nova commenta fingere, saltem in dubium revocabuntur, nec ita ferventur, maiestatis regie adversus hostes suos et fidem pugnabunt.

$6^{\circ}$. Qui ex hoc non solum Boemi, sed et omnes vicini regiones, multum scandalizabuntur, quia ipse dominus legatus dominum regem auctoritate apostolica confirmaverit regem Boemie et iam dudum predicatum sit et continue predicetur, quod sedes apostolica ipsum nunquam relinquet, prout etiam frequenter id promissum est. Nunc dicent regem per papam esse deceptum, unde considerare potest ipse papa, si hec sit via ad faciendi, quod principes de ipso et sede apostolica imposterum confidant.

$7^{\circ}$. Concludat ipse dominus Tinen. et dicat pape, quod si hoc fecerit maiestas regia, nihil aliud poterit intelligere, nisi quod et ipse pro suis servitiis pericula magna, infamias et destructiones recipiat, que omnia quali animo debeat ferre, quilibet sapiens poterit cogitare et addet ipse dominus Tinen., quod si papa nunc hoc fecerit, tantum est, ac si velit ipsum dominum regem destruere inmo si ipse legatus Ferrarien. ${ }^{36}$ contractus esset, licet dei gratia bene valet, ad huc sine predictis dampnis et scandalis revocari isto tempore non posset. Supplicet ergo dominus Tinen. pape, quod pro quanta destruction $\mathrm{e}^{37}$ ipsius regis non optat irrisionem et contemptum apostolice sedis, ut heresis incrementum ipsum dominum Ferrarien. inmo in legatione sua confirmet, nec credat, quod maiestas regia hec agat intuitu persone, quamvis ipsa sit, quod eum plurimum diligat propter virtutes suas et singularem rectitudinem ipsius et zelum ad catholicam fidem et quia semper reperit eum zelatorem iustitie sine acceptione quarumcunque personarum, sed potius maiestas regia hoc facit propter statum rerum nunc occurrentium, qui postquam mutabitur imbrevius, quod imbrevi, deo iuvante, speratur. Maiestas regia erit contenta de omni dispositione sue sanctitatis sicut antea semper fuit.

$8^{\circ}$. Dicat dominus Tinen. sanctissimo domino nostro, quod exitus rerum declaravit omnia illa vera fuisse, que presens per ipsummet sue sanctitati significavit, de quibusdem proditoribus regis, regni et fidei catholice ${ }^{38}$ et quomodo conatus tam

\footnotetext{
34 Wladislas II, King of Bohemia.

35 nam $m s$.

${ }^{36}$ Lorenzo Roverella, papal nuncio.

37 quanto destructioni $m s$.

38 captholice $m s$.
} 
perfidorum hominum istum fructum perceperit, quod et minus contra hereticos maiestas regia potuit intendere, quos usque ad ipsum diem omnino subiugasset et parum contra Turcos et quod ingressus filii Poloni ${ }^{39}$ ad Hungariam cum hereticis et Tartaris adeo nephanda et omnino paganica facinora perpetravit, qualia vix per paganos exercita fuissent in spoliatione et tractione ecclesiarum et spoliatione sacrarum reliquiarum, nam demissis reliquiis sacris tecas auri et argenti abstulerunt. Sacratissimum heukaristie sacramentum similiter vasis ablatis in terram proiecerunt, pedibus conculcarunt, virgines violarunt, pauperes non solum spoliantes, sed etiam miserabiliter trucidantes, hoc opus eorum, qui Polonos contra maiestatem regiam et regnum concitarunt, tamen divina gratia mediante ita turpiter sunt expulsi, sicut temerarie intrarunt tantaque danna perceperunt Poloni, quod vix illa sustinere ${ }^{40}$ poterunt, quia multas gentes amiserunt, multi ex eis sunt capti, omnes eis currus sunt ablati et si ante maiestatem regiam non affugissent, unus eorum non superfuisset, sed ex his sanctitas sua poterit intelligere inimicorum sue maiestati et cum quanta iniquitate processerunt non solum contra ipsum, sed potius contra omnem christianitatem. Nec credat papa, quod regia maiestas non velit de temporalibus concordari, sed nec tunc videtur cum audierit auctores et executores tanti sceleris debitam mercedem recipere.

$9^{\circ}$. Item dicat sanctissimo domino nostro, quod maiestas regia non parum miratur de tenore istarum literarum, quas sanctitas sua catholice Boemis scribit. Cum imprimo anno, quando maiestas regia nec dictam esset in regem cum efficatoribus, multum literis predecessor sue sanctitatis ipsos Bohemos hortatus fuit ad assistentiam et perseverantiam cum sua maiestate et post electionem laudati et conmendati sunt, atque affirmant ei obediendum et fortiter secum standum. Incitati inmo catholici sunt ita informati, quod credant sedem apostolicam maiestatem regiam nullo modo relicturam, a qua fide non sine eorum magna tribulatione et fidei detrimento, si litere ille presentarentur, multi possent ammoveri. Unde dicit maiestas regia, quod cum sincero animo et bona voluntate hactenus servierit apostolice sedis et propriam personam tantis periculis exposuerit nec aliquid egerit, propter quod ipsa sedes indignari debeat. Cogitur de hac re multum admirari et suspicari, quod accusatores ei non deficiant, quibus putat iustum esse, quod non credatur ipso non audito. Super hoc concludat ipse dominus Tinen., quod dominus rex recto animo semper incessit et incedere intendit, et si adiutus fuerit, sua tempora cupit contra infideles expendere et ita laborare, quod possit aut vitam mereri, possit gratiam apud deum in alia. Si autem papa vel quicunque alii deliberaverit potius audire emulos, qui sue felicitati invident et propter sua privata odia non curant impedire bonum totius christianitatis, etiam sua maiestas conmendabit se deo et sperat, quod iuvabit innocentiam suam et respiciet ad fidelia opera sua, etiam si homines noluerint illa advertere et nihilominus dicat dominus

${ }^{39}$ Casimir, the second son of Casimir IV, King of Poland.

${ }^{40}$ substinere $m s$. 
Tinen., quod semper sua maiestas parata est cuicunque stare ad ius sive parvo sive magno coram sua sanctitate et quod nunc solum propter reverenciam apostolice sedis multa maiora dampna passus est in regno suo, quod fuisset per respectum ad eam, non habuisset, nam cum iteratis vicibus oblatum fuisset regi Polonie, priusquam aliquis filiorum suorum Poloniam exiret, quod maiestas regia ne contra christianos arma sua converteret, quod nunquam nisi coactus fecit. Parata erat sive per viam amicabilis tractatus, sive per viam iustitie coram papa secum concordare, nec ille audire voluisset, quia sperabat in coniuratione proditorum, qui ei regnum promittebant et de interemptione ipsius regis [Hungarie] certificabant. Satis clarum fuit regi ipsi, quod necesse haberet ipsis occurrere et cum ad hoc se disponeret, illis ad huc extra regnum existentibus. Supervenit dominus Tilmanus ${ }^{41}$ sue sanctitatis nuncius, qui exposita legatione sua statim usque Poloniam properavit, speravit maiestas sua, quod vel ipsum pro reverencia sedis apostolice audirent. Verum aliter successit, si enim nuncius ipse advocandos ipsos missus fuisset, non cicius eius adventu percepto properassent. Que autem cum illis nuncius ipse apostolicus tractaverit, qualia ab eis responsa acceperit, si voluit, potuit sanctitati sue significare ${ }^{42}$. Hoc clarum est, quod illo ingrediente ad Poloniam illi festinarunt in Hungariam, sed ut dictum est, nec non habent gaudere de tali ingressu et deo dante in futurum minus gaudebunt. Optaret maiestas regia, si possibile esset, quod quolibet die sive nuncii sive exploratores ad ipsum venirent et eius opera scrutarentur, et sperat, quod nisi essent homines perfidissimi, afferent ei testimonium non quale emuli sue maiestati conantur suggere, sed quale bona volumptas sua et opera requirunt ac etiam merentur.

$10^{\circ}$. Dominus Tinen. dicat sanctissimi domini nostri et supplicet, quod ipsum cito et votive expediat in omnibus per maiestatem regiam postulatis et si sanctitas sua cupit proficere tam in negocio Turcorum, quam hereticorum, non teneat res diutius suspensas, nec credat, quod Poloni, qui nec deum timent, nec homines reverentur, qui propter occupanda aliena bona proprias animas perdere non curant, continue hereticos fovent, ad divina officia etiam im Polonia sine differentia admittunt, bona et patrimonium beati Petri et ecclesie Romane ac ordinis beate virginis turpiter et iniuste occupant et qui excommunicationem iam circa viginti annos non solum sustinent, ${ }^{43}$ sed contempnunt, sint illi, qui vel Turcos expugnare, vel hereticos convertere debeant, sed magis cogitet sanctitas sua, quod si maiores vires aquirent, eo priores fient, quo potentiores et tunc cum ecclesia Romana cohibere eos pro debito suo voluerit, minus poterit. Cupit maiestas regia, quod sibi saltem operibus suis sanctitas sua confidat et omnia postulata per articulos et institutiones ipsi domino Tinen. datos favorabiliter et cum debita efficacia concedat, nec dubitet sua sanctitas, quod maiestas regia nihil faciet vel disponet

\footnotetext{
${ }^{41}$ Tilmann Schlecht, papal nuncio.

${ }^{42}$ singnificare $m s$.

${ }^{43}$ substinent $m s$.
} 
sine consilio et volumptate domini legati et nunciorum suorum et quod non sit ad honorem sedis apostolice et sue sanctitatis, si vero aliter sua sanctitas decreverit et in istis dubitationibus propter maliciam hominum tempus deducere. Protestatur maiestas regia, quod si postea aliter res devenirent, quam optarent, quia a culpa illa liber esse velit. Impossibile est sue maiestati, quod contra tot tamque potentissimos hostes semper pugnare et non solum regna sua et personam suam periculis exponere diucius possit, si etiam ab illis relinquatur, qui merito eum iuvare deberent. 


\section{Archival sources}

Hungary - Budapest - Magyar Nemzeti Levéltár, Országos Levéltár, DL 14462.

Vatican City - Archivio Segreto Vaticano - Arm. XXXIX 12; Misc., Arm. II 30; Reg. Vat. 680

Vatican City - Biblioteca Apostolica Vaticana, Vat. lat. 5641, 12270.

Italy - Roma - Biblioteca Angelica, ms. 1077.

Czech Republic - Třeboň, Státní oblastní archiv, fond Historica, inv. no. 3516, sign. 2883.

\section{Published sources and literature}

Ammannati Piccolomini, Iacopo. Lettere (1444-1479). Ed. Paolo Cherubini. 3 vols. Roma: Ministero per i beni culturali e ambientali, Ufficio centrale per i beni archivistici, 1997.

Baczkowski, Krzysztof. Walka Jagiellonów z Maciejem Korwinem o koronę czeską $w$ latach 1471-1479 [The war of Jagiellonians with Matthias Corvinus for the Crown of Bohemia in 1471-1479]. Kraków: Uniwersytet Jagielloński, 1980.

Balogh, Jolán. A müvészet Mátyás király udvarában [Art in the court of King Matthias]. 2 vols. Budapest: Akadémiai Kiadó, 1966.

Bonfinis, Antonius de. Rerum Ungaricarum decades. Vol. 4/1. Ed. I. Fógel, B. Iványi and L. Juhász. Budapest: Egyetemi Nyomda, 1941.

Bónis, György. A jogtudó értelmiség a Mohács elötti Magyarországon [The legal intelligentsia in Hungary before Mohács]. Budapest: Akadémiai Kiadó, 1971.

C. Tóth, Norbert; Horváth, Richárd; Neumann, Tibor; Pálosfalvi, Tamás. Magyarország világi archontológiája 1458-1526. I. Föpapok és bárók [The archontology of Hungary, 1458-1526. I. Prelates and barons]. Budapest: MTA Bölcsészettudományi Kutatóközpont Történettudományi Intézet, 2016.

Długossius, Joannes. Annales seu Cronicae incliti regni Poloniae, Liber duodecim, 1462-1480. Ed. Krzysztof Baczkowski et al. Kraków: Polska Akademia umiejętności, 2005.

Engel, Pál. The Realm of St Stephen: A History of Medieval Hungary, 895-1526. London: I.B.Tauris, 2001.

Eubel, Conradus. Hierarchia catholica medii aevi sive Summorum pontificum, S. R. E. cardinalium, ecclesiarum antistitum series ab anno 1431 usque ad annum 1503 perducta. Munich: Libraria Regensbergiana, 1914.

Fletcher, Catherine. Diplomacy in Renaissance Rome: The Rise of the Resident Ambassador. Cambridge: Cambridge University Press, 2015. 
Fraknói, Vilmos, ed. Mátyás király levelei, külügyi osztály [The letters of King Matthias, foreign section]. 2 vols. Budapest: Magyar tudományos akadémia, 1893 $-1895$.

Fraknói, Vilmos. "Mátyás király magyar diplomatái" [Hungarian diplomats of King Matthias], Századok 32 (1898): 1-14, 97-112, 385-404, 481-489, 769-781, 865-875; 33 (1899): 1-8, 291-309, 389-410, 773-787, 869-878.

Kalous, Antonín. Matyáš Korvín (1443-1490): Uherský a český král [Matthias Corvinus (1443-1490): King of Hungary and Bohemia]. České Budějovice: Veduta, 2009.

Kalous, Antonín. Plenitudo potestatis in partibus? Papežští legáti a nunciové ve střední Evropě na konci středověku (1450-1526) [Papal legates and nuncios in late medieval Central Europe (1450-1526)]. Brno: Matice moravská, 2010.

Köblös, József. A budai, fehérvári, győri és pozsonyi káptalan archontológiája, 1458-1526 [The archontology of the chapters of Buda, Fehérvár, Györ and Pozsony (Bratislava)]. Budapest: Magyar országos levéltár, 1987.

Köblös, József. Az egyházi középréteg Mátyás és a Jagellók korában (A budai, fehérvári, győri és pozsonyi káptalan adattárával) [The ecclesiastical central layer in the period of King Matthias and the Jagiellonians (With the database of the chapters of Buda, Fehérvár, Győr and Pozsony /Bratislava/)]. Budapest: MTA Történettudományi Intézete, 1994.

Kronthal, Berthold; Heinrich Wendt, eds. Politische Correspondenz Breslaus im Zeitalter des Königs Matthias Corvinus, erste Abtheilung, 1469-1479. Breslau: Josef Max \& Comp., 1893. (Scriptores rerum silesiacarum 13.).

Kubinyi, András. "Vitéz János és Janus Pannonius politikája Mátyás uralkodása idején" [The politics of John Vitéz and Janus Pannonius during the rule of Matthias]. In: Humanista müveltség Pannóniában [Humanist culture in Pannonia], ed. István Bartók, László Jankovits and Gábor Kecskeméti, 7-26. Pécs: Müvészetek Háza-Pécs Tudományegyetem, 2000.

Kubinyi, András. "Vitéz János: a jó humanista és rossz politikus" [John Vitéz: a good humanist and bad politician]. In: A magyar történelem vitatott személyiségei [The controversial figures of Hungarian history], vol. 2, 7-30. Budapest: Kossuth Kiadó, 2003.

Kubinyi, András. Matthias Corvinus: Die Regierung eines Königreichs in Ostmitteleuropa 1458-1490. Herne: Tibor Schäfer, 1999.

Kubinyi, András. Matthias Rex. Trans. Andrew T. Gane. Budapest: Balassi Kiadó, 2008.

Lazzarini, Isabella. Communication and Conflict: Italian Diplomacy in the Early Renaissace, 1350-1520. Oxford: Oxford University Press, 2015. 
Macek, Josef. "Prag und Rom am Ende des 15. Jahrhunderts: Zum Verhältnis der päpstlichen Kurie zur böhmischen Reformation”. In: Historische Blickpunkte: Festschrift für Johann Rainer, ed. Sabine Weiss, 391-403. Innsbruck: AMOE, 1988. (Innsbrucker Beiträge zur Kulturwissenschaft 25).

Mályusz, Elemér. Egyházi társadalom a középkori Magyarországon [Church society in medieval Hungary]. Budapest: Akadémiai Kiadó, 1971.

Narducci, Henricus. Catalogus codicum manuscriptorum praeter graecos et orientales in Bibliotheca angelica olim coenobii sancti Augustini de Urbe, Tomus prior. Roma: Ludovico Cecchini, 1893.

Stenzig, Philipp. Botschafterzeremoniell am Papsthof der Renaissance: Der Tractatus de oratoribus des Paris de Grassi - Edition und Kommentar. 2 vols. Frankfurt am Main: Peter Lang, 2013.

Theiner, Augustinus, ed. Vetera monumenta historica Hungariam sacram illustrantia. Vol. 2, Ab Innocentio PP. VI. usque ad Clementem PP. VII, 1352-1526. Roma: Typis Vaticanis, 1860. 


\title{
Kralj Matjaš Korvin i papinstvo početkom 1472. godine: Miklós Nyújtódi Székely u Rimu
}

\author{
Antonín Kalous \\ Katedra historie Filozofické Fakulty \\ Univerzity Palackého v Olomouci \\ Kř́ižkovského 10 \\ 77180 Olomouc \\ Republika Češka \\ E-adresa: antonin.kalous@upol.cz
}

\section{Sažetak}

Ugarski kralj Matjaš Korvin održavao je bliske kontakte s papinstvom te je nastojao ispuniti nekoliko zadaća koje je papa od njega zatražio. Te su zadaće krajem šezdesetih i početkom sedamdesetih godina 15. stoljeća bile uglavnom povezane s Češkom i suzbijanjem "heretik," a samim time i s Poljskom uslijed borbe za češku krunu. Spomenute kontakte valjalo je održavati posredstvom diplomata s obiju strana, odnosno papinskih legata i nuncija. Miklós Nyújtódi Székely bio je jedan od diplomata u službi kralja Matjaša. Potjecao je iz transilvanijskog plemstva, a studirao je u Beču i Italiji. Tijekom bečkih studija postao je kanonik u Székesfehérváru, a kasnije je stekao i druge crkvene nadarbine, ukjučujući kninsku biskupiju 1467. godine. Sveučilišno obrazovanje i crkvene nadarbine definirale su živote mnogih osoba koje je ugarski kralj želio koristiti kao diplomate. Biskupovo djelovanje dobro je poznato, a osobito ga je detaljno prikazao Vilmos Fraknói u studijama o diplomatima u službi kralja Matjaša. No iako mu je bilo poznato da je Miklós predvodio izaslanstvo u Rim početkom 1472., nije se znalo o kojim se specifičnim zadaćama radilo. Međutim, jedan rukopis u rimskoj Biblioteca Angelica sadrži tekst pod naslovom Informatio domini Tininien. ex parte maiestatis regie, skup detaljnih uputa za pregovore pri papinskoj kuriji u Rimu. Ovaj tekst otkriva kraljeve namjere i poteškoće, budući da on nije bio zadovoljan nedostatkom papine podrške, a uz to je bio uznemiren stanjem u srednjoj Europi te postupcima svojih protivnika u Češkoj i osobito u Poljskoj. Stoga je istaknuo razaranja koja su nanijele poljske vojne operacije 1471. Također je istaknuo svoju spremnost da se bori na strani papinstva, no zauzvrat je tražio jasan izraz podrške protiv svojih neprijatelja u regiji. Tekst jasno pokazuje kako je kralj želio da papa zadrži tadašnjeg nuncija Lorenza Roverellu na položaju. Nakon razgovora u Rimu Nyújtódi je ostao u kontaktu s novim legatom u regiji Marcom Barbom, koji je došao kako bi vodio mirovne pregovore između kršćanskih vladara. Ove upute i 
drugi povezani dokumenti pokazuju način na koji je funkcionirala diplomatska služba te otkrivaju kraljeve namjere i planove na prijelomu 1471. i 1472. godine.

Ključne riječi: papinstvo, papinska diplomacija, Lorenzo Roverella, Matjaš Korvin, Ugarska, Češka, srednja Europa, Miklós Nyújtódi Székely, diplomacija 